\title{
Alternative dispute resolution (ADR), the best option in family matters
}

\section{Medios alternativos de solución de controversias (MASC), la mejor opción en materia familiar}

GONZÁLEZ-HERNÁNDEZ, Daniel Antonio†*, REJÓN-JIMÉNEZ, Ysela, TEJERO-BOLÓN, Francisco Javier and VÁZQUEZ-HEREDIA, Pablo Rafael

Universidad Autónoma del Carmen, Mexico.

ID $1^{\text {st }}$ Author: Daniel Antonio, Gonzalez-Hernández / ORC ID: 0000-0003-4730-7029, Researcher ID Thomson: G-20532018, CVU CONACYT ID: 900016

ID $1^{\text {st }}$ Coauthor: Ysela, Rejón-Jiménez / ORC ID: 0000-0002-7829-5457, Researcher ID Thomson: G2089-2018, arXiv ID: ysela60, CVU CONACYT ID: 900052

ID $2^{\text {nd }}$ Coauthor: Francisco Javier, Tejero-Bolón / ORC ID: 0000-0002-6561-5618, Researcher ID Thomson: G-2461-2018, arXiv ID: FranciscoTejero, CVU CONACYT ID: 900093

ID $3^{\text {rd }}$ Coauthor: Pablo Rafael, Vázquez-Heredia / ORC ID: 0000-0002-2906-2323

DOI: $10.35429 /$ EJM.2020.24.11.12.23

Received January 12, 2020; Accepted June 30, 2020

Abstract

The objective of this research project is to show in concrete terms the importance of Alternative Dispute Resolution Means in family matters, as well as all the benefits and advantages of resorting to them. It is noteworthy that the Alternative Dispute Resolution Means, as mentioned below, we can call them novel, but not new, since they existed in some procedural legal areas already in application, such as Agrarian Law, Labor Law and in some administrative procedures such as procedures before the Federal Consumer Protection Agency. However, its incorporation as an immediate resolution of a conflict in all legal areas and prior to, and even after having initiated the procedure, is what makes this something new, which will allow those who resort to the utility of these Mechanisms, to a more prompt justice, to obtaining his justice, and to the satisfaction of his claim by giving this same possibility and opportunity to the one with whom the conflict has been had. This sample will be carried out, through the application of surveys and the realization of a brief study compared with other countries, that allows us to propose ideas and later strategies for a correct diffusion of these alternative media to society in general, which great part of this is still unknown. The possible results that we intend to obtain through the application of the surveys is to know the knowledge that society has in our environment about the existence of these alternative mechanisms, and how much they know about them, how much population approximately knows about them, as well as whether have resorted to them, how many people have resorted to and if so, how efficient and effective they consider the use of these mechanisms. This work will be carried out under an exploratory-descriptive approach, in the same way a data collection will be used in a quantitative way, since surveys will be applied to demonstrate the level of knowledge on the subject to be studied among the selected population. The contribution of this project will be to publicize, inform and bring the population closer to opting for Alternative Dispute Resolution Mechanisms as the first option to resolve their family legal disputes, thus avoiding long and costly processes, opting for a solution through the culture of peace, free and fast.

\begin{abstract}
Resumen
Este proyecto de investigación tiene como objetivo, mostrar en rasgos concretos la importancia que tienen los Medios Alternativos de Solución de Controversias en materia familiar, así como todos los beneficios y ventajas de recurrir a ellos. Es de destacar, que los Medios Alternos de Solución de Controversias como se ha de mencionar más adelante, podemos denominarlos novedoso, mas no nuevo, puesto que existían en algunas áreas jurídicas procesales ya en aplicación, como en el Derecho Agrario, Derecho Laboral y en algunos procedimientos administrativos como en procedimientos ante la Procuraduría Federal del Consumidor. Sin embargo, su incorporación como una inmediata resolución de un conflicto en todas las áreas jurídicas y de manera previa, e incluso, posterior a haber iniciado el procedimiento, es lo que hace de este algo novedoso, que permitirá a quien recurra a la utilidad de estos Mecanismos, a una justicia más pronta, a la obtención de su justicia, y a la satisfacción de su pretensión dando esta misma posibilidad y oportunidad a aquel con quien se ha tenido el conflicto. Esta muestra se llevará a cabo, a través de la aplicación de encuestas y la realización de un breve estudio comparado con otros países, que nos permita plantear ideas y posteriormente estrategias para una correcta difusión de estos medios alternativos a la sociedad en general, que gran parte de esta los desconoce aún. Los posibles resultados que pretendemos obtener mediante la aplicación de las encuestas, es saber el conocimiento que tiene la sociedad en nuestro entorno acerca de la existencia de estos mecanismos alternos, y que tanto conocen de ellos, cuanta población aproximadamente conoce de ellos, así como si han recurrido a ellos, cuanta gente ha recurrido y de ser así, que tan eficiente y eficaz consideran la utilización de dichos mecanismos. Este trabajo se efectuará bajo un enfoque exploratorio-descriptivo, de igual forma se hará uso de una recolección de datos de forma cuantitativa, debido a que se aplicarán encuestas para demostrar el nivel de conocimiento sobre el tema a estudiar entre población seleccionada. La contribución de este proyecto será dar a conocer, informar y acercar a la población a que opten por los Mecanismos Alternativos de Solución de Controversias como primera opción para resolver sus controversias legales familiares, evitando así largos y costosos procesos, optando por una solución mediante la cultura de paz, gratuita y rápida.
\end{abstract}

MASC, Familia, Derecho

Citation: GONZÁLEZ-HERNÁNDEZ, Daniel Antonio, REJÓN-JIMÉNEZ, Ysela, TEJERO-BOLÓN, Francisco Javier and VÁZQUEZ-HEREDIA, Pablo Rafael. Alternative dispute resolution (ADR), the best option in family matters. ECORFAN Journal-Mexico. 2020. 11-24:12-23.

$\uparrow$ Researcher contributing first author. 


\section{Introduction}

Every individual has their own ideals, beliefs, convictions and diverse ways of solving the situations that arise from day to day in everyday life. Due to these different ways of thinking between individuals, we consider it normal that there are always disagreements between two or more people on different topical aspects, tendencies, preferences, beliefs, etc., including also those related to Law, and specifically as the basis of our work. , Family Law.

A large part of the general population has the belief and therefore the knowledge that the only way to solve legal problems of a family nature is by hiring the services of a lawyer, who will provide technical assistance in the preparation of the respective jurisdictional process. , that is, an extensive and expensive trial, which, in a mechanized way, if said professional is lacking in probity, will only seek to win the case and sometimes even harm the other party, forgetting whether or not the client is entitled to , the satisfaction of the demanded and above all the obtaining of real justice, leaving it to the design of a sentence handed down by a judge.

This is where a very important figure for the resolution of these conflicts comes in, such as the Alternative Dispute Resolution Means (ADR), which are presented as the fastest and most effective way to resolve legal issues, including family law, The same that, resolved through a trial, would be tedious, long and expensive; That is why the consideration of ADR as an inclusive part of the culture of peace, offers and grants a fast and effective alternative, thus facilitating to a great extent, the resolution of controversies between the parties, through the signing of agreements where both parties make a profit and are not affected.

The ADR allow the participants the private solution of conflicts or controversies among themselves, based on principles that govern it for the proper development and to reach the preponderant objective that is the satisfaction of the parties, (as in the case of mediation and negotiation) or by the intervention of an impartial third party who proposes or dictates solutions (such as conciliation and arbitration); these alternative means are generally handled by sessions and the parties can decide when to end the dispute by reaching an agreement at any time during the session.
Unfortunately, despite how effective, fast and economical it is to resort to these alternative solutions, it is still an alternative little used and we could well say, unknown to society, this mainly due to the lack of dissemination and culture of the peace among citizens, so strategies must be sought and proposed to be able to insert the existence and convenience of these mechanisms, in the mentality of the people, so that it is their first option before even thinking about the possibility of starting an annoying and tired judgment.

The Alternative Means of Dispute Resolution is the proposal of the culture of peace, to solve family conflicts, being something equitable and fair for the parties. Citizen training in the culture of peace will allow citizens to generate actions and commitments to resolve their disputes in a peaceful manner and promote action while respecting the rights of others and the laws that protect them. In particular in family matters, it is essential that society has training in the culture of peace since it is where the socialization of the human being begins.

\section{Discussion}

\section{Concept of ADR}

Conflicts are part of the nature of the human being, legally when a person is violated a right this has different ways of enforcing what it deems appropriate. On many occasions, these forms attract various legal consequences, in this sense the laws have evolved to provide alternatives for the parties to quickly resolve their conflicts Lara Mendoza M. (2008).

It is in this part, is where "Alternative Dispute Resolution Means" (ADR) come in, which are tools that are increasingly used to resolve disputes in a friendly manner and without the need to resort to adversarial means, such as the litigation. Cossío González F. (2014). These means encompass different possibilities that people involved in a legal problem have to solve it, as mentioned before, without the intervention of a judge or a judicial process, so they are solved in an expeditious, simple, agile, efficient way, effective and with full legal effects.

The protagonists at all times are the parties, they seek the solution to the conflict directly between them (negotiation) or through the intervention of an impartial third party (such as mediation, conciliation and arbitration). 


\section{ADRs in Mexico}

With regard to the Mexican country, it has been immersed since time immemorial in endless disputes and conflicts between its inhabitants, day by day the number of complaints, lawsuits and trials that are being carried out and those that are remain to be resolved; Therefore, the judicial system is being stunted, causing an accumulation of unresolved situations that indirectly forces the jurisdictional authorities to violate the principle of prompt and expeditious justice.

Alternative Dispute Resolution Means arise in Mexico precisely from the need to modernize the traditional justice system, with the clear objective of offering citizens a simple, fast and economical option to solve their conflicts and, incidentally, decongest the burden of work that exists in the courts of the different judicial districts of the country.

The first incorporation of these mechanisms to the Mexican Judicial Power occurred in Quintana Roo in 1997, when the Alternative Justice Law was published and consequently the first Legal Assistance Center was created, this was a decentralized body of the Judicial Power, whose primary objective It was for individuals to resolve their disputes of a legal nature of an exclusively private nature; Therefore, it is important to note that many of the states followed the example of Quintana Roo, by implementing an alternative justice law and creating institutions belonging to the Judiciary to offer mediation and conciliation services. Breceda Pérez J. A. (2017).

However, despite the efforts of several states to implement external solutions, they could not be consolidated because they were unknown methods and not completely governed by law; This changed radically with the reform of article 17 of the Federal Constitution in 2008, which states: "The laws will provide for alternative dispute resolution mechanisms."

Here the ADRs managed to gain a bit of prominence in the country, by virtue of the fact that it is recognized for the first time as a human right and as a constitutional guarantee the possibility of the parties to resolve their conflict without the need for the State to intervene. In a direct way.
After this important constitutional reform, the federal Judicial Power stated that both judicial protection and alternative dispute resolution mechanisms are on the same constitutional level, with the same dignity, legal force and with the same purpose: to solve conflicts. Nava González W. (2017)

\section{ADRs in other countries (Comparative Law)}

In order to carry out a complete and in-depth study about Alternative Dispute Resolution Mechanisms applied in the family environment in order to visualize their correct application and dissemination to society, it is important to carry out an analysis compared with other countries to verify how these, They have been carrying out the application of the mechanisms, their results, their significance, and the differences or similarities between Mexican and foreign legislation. It should be noted that in some countries they have highlighted some mechanisms over others, being able to use only some alternatives of all the existing ones to resolve their family conflicts, such as mediation.

To begin with, mediation as it is known today is an adaptation of what already existed in other cultures ages ago; For example, in China it was a basic resource in the resolution of disagreements and today it is still exercised through the popular conciliation committees Xinwei L. (2017).

Along the same lines, in addition to China, Argentina is another of the countries that is involved in the ADR issue, specifically in mediation; Such is the case that Law 24573 of October 4, 1995 relative to Civil and Commercial Mediation and Conciliation began to apply from April 23, 1996. In its first article it establishes that "family matters may be the subject of mediation in both are not excluded from it "; imposing a strict and mandatory nature of this prior, extrajudicial means in all trials, excepting cases of separation and divorce, marriage nullity, filiation and parental authority, as well as the patrimonial issues derived from these in which case the judge must divide the processes, excluding the mediator's patrimonial part, which will have the objective of promoting communication between the parties to the dispute. However, the parties may be exempt from this compliance if they prove that there was a mediation process before the corresponding Ministry of Justice before the start of the case. 
This law establishes that among the requirements to be a mediator is being a lawyer and having had the required training. Differentiating it from Mexican legislation, in our country this figure may not only be a lawyer but also a psychologist or social worker; This is due to the importance of the mediator knowing how to handle the issues to be discussed, as well as the emotions involved in them. However, it has the similarity with other laws, including ours to provide for the creation of Registries of Mediators, but regarding its constitution, organization, updating, and administration, it will be the responsibility of the Ministry of Justice of the Argentine Nation.

Now, since in Argentina one of the fundamental and mandatory requirements is mediation to initiate a judicial process, it is to be expected that the law itself will establish judicial approval in the event that the mediators reach agreements in said procedure. For this reason, Argentina is considered to be one of the most advanced and experienced countries in terms of the family mediation process, not only due to the fact that it has a law that not only establishes the binding nature of the final agreement between the mediators, but also the enforceable force that these agreements have, thereby giving security and certainty to the people immersed in the mediation process, a process that is required to be established prior to a judicial process, thereby seeking that the parties themselves reach the resolution of their conflicts.

Speaking of the first developed countries on the subject of mediation in family matters in Europe, England and France were the pioneers in developing it, being that, in Germany, Belgium, France, England, Wales, Ireland, the Netherlands and Switzerland, it is a common and widely used process.

In Norway, for example, it is mandatory to attend the first mediation information session when there are children under the age of 16 in the separation process, which could be taken into account in our mediation legislation to prioritize the best interests of girls, children and adolescents.
The first experiences of family mediation appeared in Spain timidly in the second part of the eighties, being implanted and spreading during the nineties, currently finding ourselves in a moment of attempting to generalize its use through its legal regulation through laws, autonomic family mediation. The pioneering Autonomous Communities in the application of family mediation programs were Catalonia and Galicia.

The different family mediation laws are proof of the progress that is taking place in the implementation of the culture of mediation in Spain. Catalonia was the first region where family mediation was regulated (Law 1/2001 of Catalonia). It was followed by Galicia (Law 4/2001), Valencia (Law 7/2001), the Canary Islands (Law 15/2003), Castilla La Mancha (Law 4/2005), the Balearic Islands (Law 18/2006), Castilla y León (Law 1 / 2006), Madrid (Law 1/2007), Asturias (Law 3/07) and the Basque Country (Law 1/08).

Several of these Autonomous Communities already have Family Mediation Regulations: Catalonia, Galicia, Canarias, Castilla León.

The rest of the Autonomous Communities without a mediation law plan to approve it in the coming years.

A comparative reading of them shows considerable differences in terms of what type of conflicts will be mediated, the conditions for professionals to act as mediators and in relation to the concept of mediation.

Work is being done on the development of a state family mediation law that unifies the foundations and basic aspects of this professional activity.

The aforementioned European Union directive on aspects of mediation in civil and commercial matters must also be transposed into Spanish law in the coming years.

Family mediation encompasses several types of mediation depending on who its members are. Intergenerational mediation between parents and children is very useful to help overcome the crisis of the family life cycle that appears between parents and adolescents. Sibling mediation to organize the care of disabled parents is expanding due to the aging of the European population. Another modality is mediation in family businesses. 
Family Mediation is being carried out at a private and public level in Spain. Subsidies have been granted since the 1990s to offer this resource free of charge to the population. Some Programs offer only mediation, but in most cases this help is offered along with others that complement it, such as family counseling or therapy.

The Family Guidance Centers (COF) were the prelude to the current Family Support Centers (CAF) that in Town Halls such as Madrid offer guidance, mediation and family therapy.

The current trend is to create Centers that offer the greatest possible number of resources that a family may need throughout the life stages it is going through. It is intended to work from an ecological and interdisciplinary model, in which the user can receive several simultaneous interventions without having to travel to different places, which allows a more specialized and appropriate attention to their interests.

\section{ADR in Family Matters}

Now, entering these alternative mechanisms in the family sphere, in Mexico, the figure of mediation is mainly used to resolve conflicts of this nature. For the author Lisa Parkinson (2005), family mediation is "a process in which an impartial third person helps those involved in a family breakdown, and especially couples in the process of separation or divorce, to communicate with each other and to reach their own joint decisions, on the basis of sufficient information, regarding some or all of the issues related to separation, divorce, children, the economy or family wealth. "

Fernando Romero Navarro (2002), conceives family mediation as "an intervention in a conflict or a negotiation by a third person acceptable to the parties, impartial and neutral without any decision-making power and that aims to help them to themselves develop an arrangement that is workable, satisfactory and capable of meeting the needs of all members of a family, particularly those of sons and daughters."
From what has already been stated, it can be understood in a broad sense that family mediation (the most used alternative in Mexico) is the cooperative system for managing and resolving conflicts between the members of a family that, Through a non-jurisdictional, voluntary, confidential process, facilitated by the mediator, who is an impartial, neutral third party, suitably trained and without any power of decision; It enables communication between the parties so that they try to translate common interests into a viable and stable agreement that is satisfactory for both, and also meets the needs of the family group, especially those of minors and the disabled.

The family is a system made up of subsystems, the conjugal, the parental and the fraternal, so the person immersed as a mediator must work taking into account the above, prioritizing the best interests of girls, boys and adolescents to guarantee their healthy developing.

However, even when the mediator works in an agile and economical way, focusing on the emotions and needs of the members of a family, with the participation of the judge with knowledge of the matter, it is difficult to achieve a solution, since the authority usually puts more emphasis on litigation, since traditionally it is well known that in a judicial process one party loses and the other wins. Despite this procedural inequality, ADR benefits to recover the functionality of the family and to preserve it.

\section{Objectives and Purpose of ADR (Family Matters)}

As mentioned above, the family is the pillar and nucleus of society, that is why the Law and regulations seek to protect this institution by the possible means; However, it is not incorrect to say that the family is greatly affected in a jurisdictional process.

This is where the Alternative Dispute Resolution Means come in, which aim not only to solve a conflict between family members, but also to bring them back together or that there is simply no sense of guilt, loss or resentment.

To fulfill their purpose, these mechanisms are in charge of resolving matters of any family nature, among which are: 
- Conflicts between parents, siblings, adopted children or any other relative.

- $\quad$ Conflicts generated by an inheritance.

- $\quad$ The change of housing.

- $\quad$ The use of the marital home.

- Guard and custody of the minor children.

- $\quad$ Obligations acquired in marriage.

- $\quad$ Liquidation of the conjugal union.

- Parental authority (shared or with exceptions).

- $\quad$ Alimony for the minor children and in some cases for him or the spouse.

- Visitation of minor children.

- $\quad$ Separation of Property.

The main objectives to be achieved with the use of ADR in this matter are:

- That the parties in conflict reach an agreement that is equitable, fair and does not involve more problems in the future.

- Facilitate communication and therefore dialogue with those involved for a peaceful and welcoming chat.

- Get correct solutions and not hasty or forced to each specific case.

- Reestablish or strengthen family relationships.

- Reach agreements that benefit the participants and are lasting.

- Demonstrate the effectiveness of these mechanisms so that they are increasingly implemented in the consciousness of society.

Consequently, it could be said that family mediation helps to reestablish relationships affected by some destructive attitudes, it is obviously a rescue factor for family problems Pesqueira L. J. (2009: 45).

\section{Advantages and disadvantages of ADR (Family Matter)}

Alternative media have evolved and have been increasingly accepted by professionals and legal scholars, this has not happened by coincidence; but rather because of the great number of advantages represented by resorting, for example, to family mediation than to the traditional adversarial system.

To mention some benefits we have the following:

- Less procedural burden for the judiciary, which allows for a faster and more efficient solution of cases that are pending, or that cannot be resolved by their nature through an alternative mechanism, instead of continuing to accumulate unresolved files.

- It allows the rescue of the family institution in society, so a problem could be solved that, solved with a jurisdictional authority, could have been fractured and not function again with the principles of a family.

- It is totally free to start an alternative method and there are no extra costs during the entire time the mediations are taking place; which means a great support for the parties, since in general the fees of the lawyers are usually high.

- All agreement is based on peaceful dialogue between the parties; so they can express their emotions, understand and respect the position of the other person, improve the relationship of the participants, get the parties to take responsibility for their conflicts and increase creativity in generating solutions for future problems.

- Establishment of agreements through the autonomy of the will of the parties, which allows that there are no future problems to comply with the agreement.

- Sense of satisfaction when signing the agreement, so that one of the parties does not contract that resentment of losing the case that could originate in negative personal wishes or permanent displeasure that if they happen at the end of a traditional trial. 
However, it is also necessary to mention the disadvantages that ADRs represent in family matters, they do not overshadow their benefits, much less make them stop being a highly recommended option; it is only the need to list them:

- Lack of knowledge of the population about alternative methods; is the main disadvantageous reason for these mechanisms, they have not really been given enough publicity to be implanted in the mentality of society, so when they are presented with a legal problem, the first thing they will have in mind is to sue and start a trial, not because they want to, but because they believe it is the only way to do justice and get what they want.

- They are not mandatory to obtain a result; These media, despite all the aforementioned benefits, do not have the coercive force that, if they have the judicial decisions, so entering one or ten mediation sessions does not ensure being able to solve the conflict, much less signing an agreement.

- They may not be suitable to carry out all family conflicts, only a few; Some example of this is in the case of domestic violence, in conflict resolution where there were previously physical or verbal aggressions, situations where a spouse has never been responsible for a minor and has no interest in doing so, among others of equal magnitude.

\section{How much does society know about ADRs?}

To know and verify the data on the lack of knowledge of the society about the alternative mechanisms of conflict resolution, a survey was formulated and applied to the university community (students, teachers and staff in general) and people in general over 18 years of age in City of Carmen, Campeche. The objective and purpose of this work tool was to collect data about the level of knowledge that the population has about ADRs to later show the importance they have and the advantages of resorting to them, all with the purpose of planning and establishing strategies for its correct diffusion by the corresponding means. A comparative table is attached below for the purposes of greater understanding in relation to the advantages and disadvantages of ADR (Family Matter).

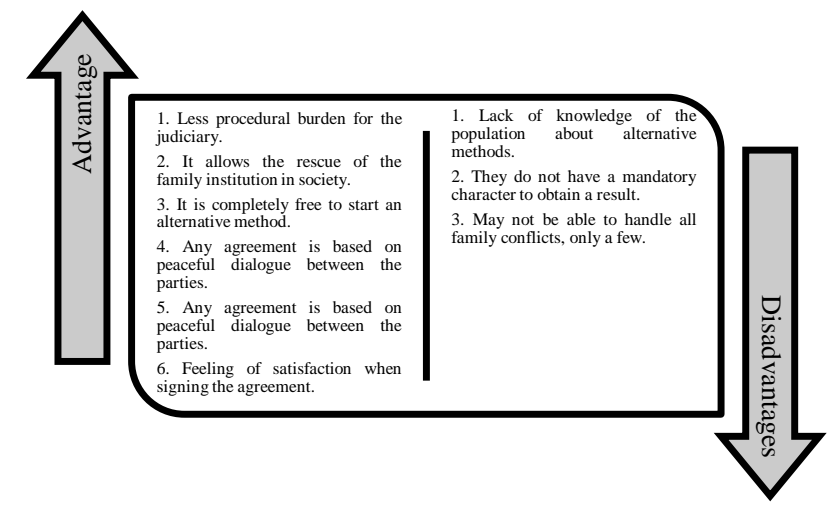

Figure 1

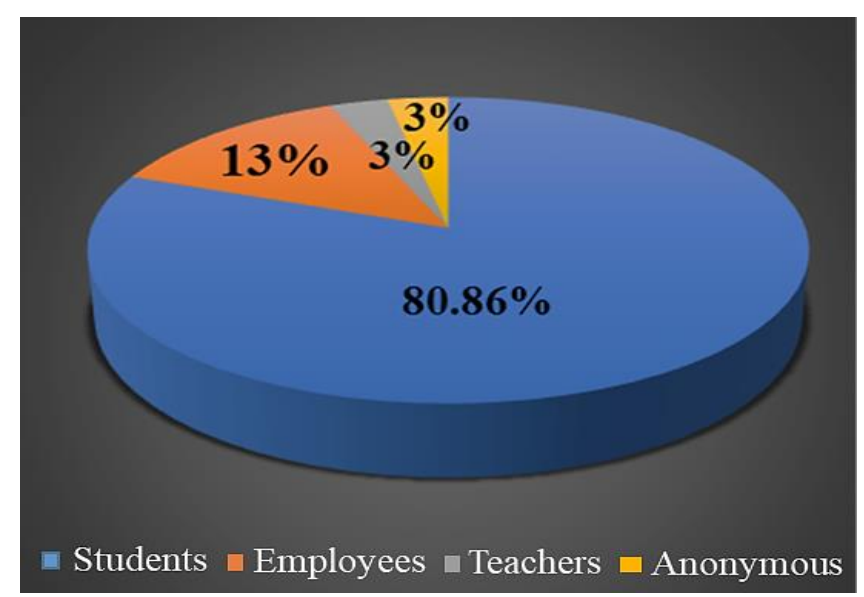

Graphic 1 Sample surveyed

Only nine questions were posed, since they were the essential ones to cover the most relevant aspects on the subject, it was taken into account that an excessive number of them would predispose respondents to reject the survey or to respond without a minimum reflection, which would complicate the elaboration of this analysis.

In order for the sample of people to understand what it was about; they were given a brief explanation of the purpose and a short but understandable concept of ADR. The results of the surveys were entered into a database, which made it possible to obtain specific statistics for each response. Below are the graphs of the data collected from the nine most relevant questions that were answered in the surveys. 


\section{Question 1}

Have you heard about ADRs?

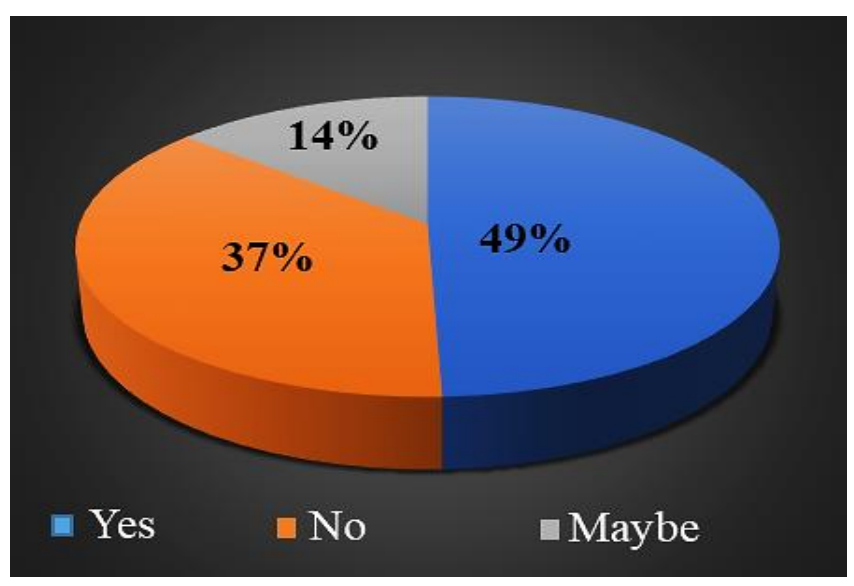

Graphic 2

As can be seen, here $37 \%$ of those surveyed answered that they had not heard about alternative media, as opposed to $49 \%$ who had heard about them; What is perceived is that little by little the population is becoming more informed about these mechanisms, however, ADRs do not permeate most of society, it should also be noted that the survey was conducted with students and teachers of the Law degree, it is true that still the vast majority of people attend the Courts to resolve their issues and at that time they are aware that they can do it peacefully, using ADR, but this is only a small part, without However, it does not mean that both the structures and the legislation created to resolve their issues are unviable.

Here it is true that ADRs have been created to quickly and peacefully facilitate the resolution of conflicts between parties, but due to the little publicity they have among the population, it means that in most cases they do not occur in this way.

This does not mean that the legal structure is unviable, but rather it is the ignorance of this figure before society that makes its use impossible.

\section{Question 2}

Have you been through a legal problem in family matters?

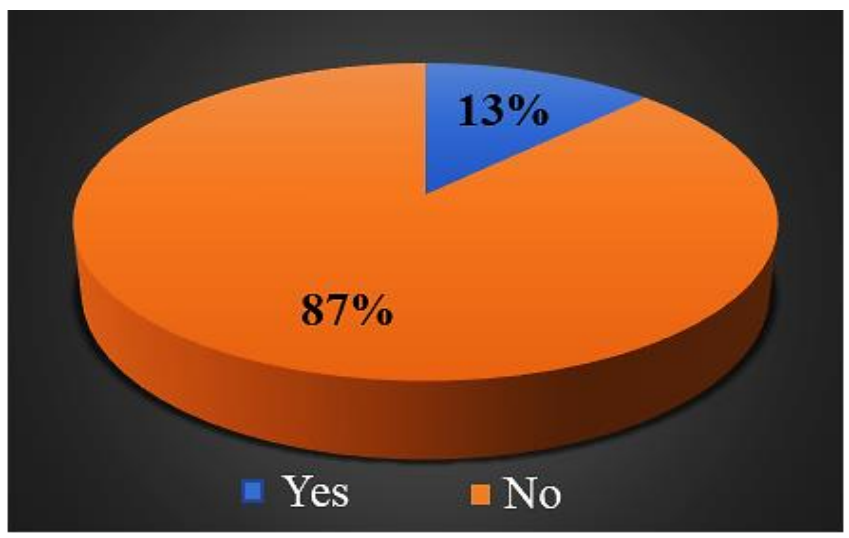

Graphic 3

Fortunately, only $15 \%$ of the sample surveyed has been involved in problems of a family nature, which results in satisfactory data because $85 \%$ of the families of these people are managing their situation in a harmonious and calm way; solving your problems at home and not transcending your internal conflicts.

\section{Question 3}

If your answer was yes, did you resort to ADRs?

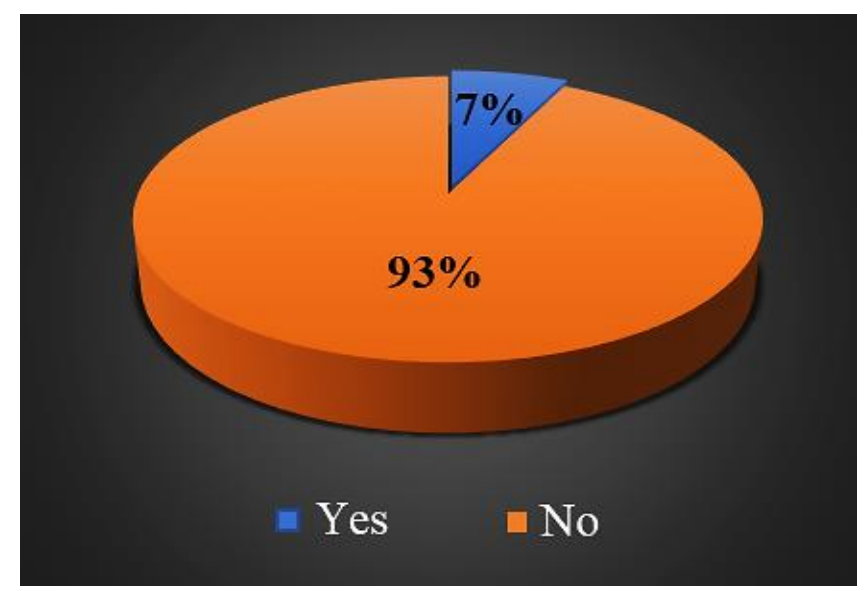

Graphic 4

As can be seen in the figure, only $7 \%$ of those who had family legal problems occurred to ADRs, which follows that the vast majority of respondents have not had any legal problem that makes them go to investigate which would be the fastest way to resolve a legal matter in family matters. The above reaffirms what has already been stated above, the great ignorance of the subject forces the people involved to adhere to a process before a judge, when they really wanted to resolve it peacefully and that both could express their positions on the matter to reach an agreement.

\section{Question 4}

Do you know someone who has had a family problem and has resorted to ADR?

GONZÁLEZ-HERNÁNDEZ, Daniel Antonio, REJÓN-JIMÉNEZ, Ysela, TEJERO-BOLÓN, Francisco Javier and VÁZQUEZHEREDIA, Pablo Rafael. Alternative dispute resolution (ADR), the best option in family matters. ECORFAN Journal-Mexico. 2020 


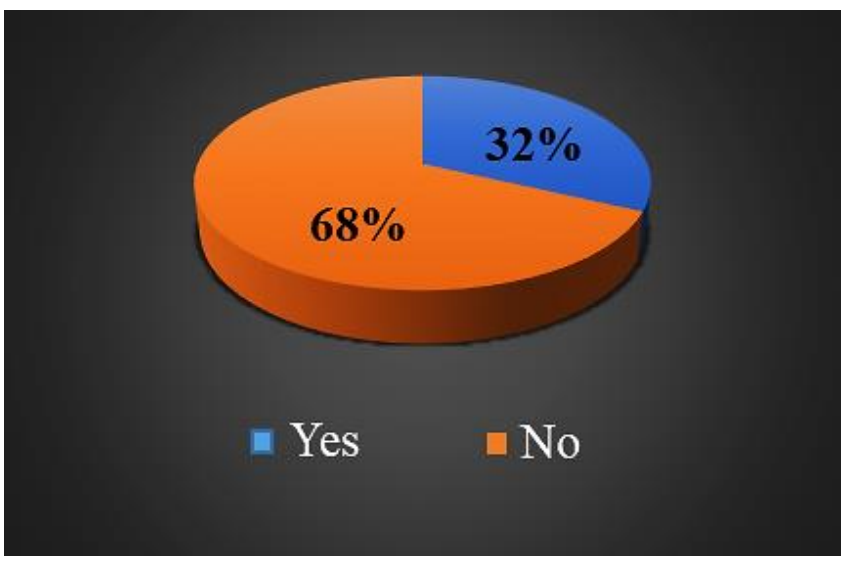

Graphic 5

With this question, it is noted in the answers given that there are no concrete data, because $68 \%$ of the refusals do not refer precisely to the fact that their acquaintances did not resort to alternative media; rather, they did not actually have the memory of any person who had had a legal problem of a family nature.

Even so, 32\% answered affirmatively, which weighs the fact that, if there is a significant number of people, independently of those surveyed, who know and have used these mechanisms; Therefore, the fact that the population of Ciudad del Carmen lives completely in ignorance of this issue cannot be assumed. This means that there is a need to disseminate ADRs to society in general, either through the bar or bar association or through newsletters, information on ADRs, and in this way establish links between society and professionals in the field of Law, so that the new form of conflict resolution permeates society

\section{Question 5}

Do you consider that ADRs are an effective means of prompt justice?

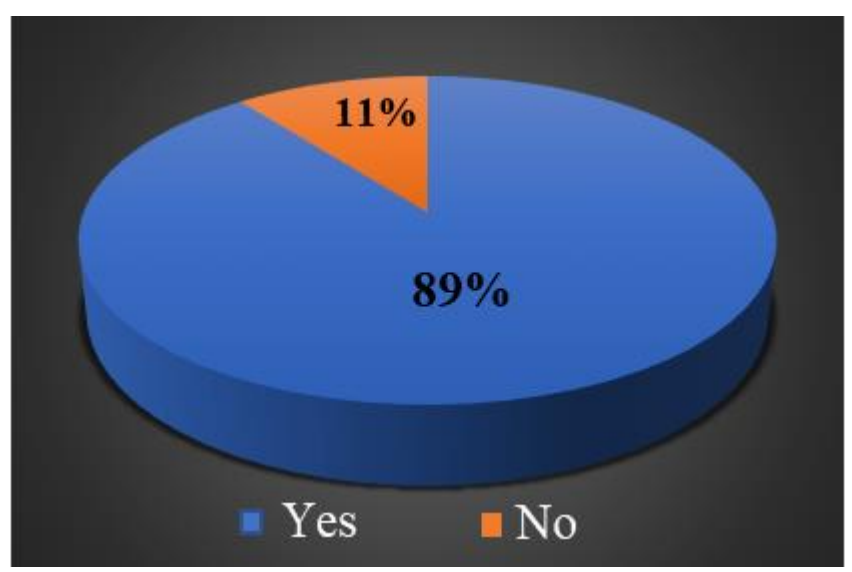

Graphic 6
Due to the introductory information that was given about alternative means and the growing doubts that were resolved by the respondents, $89 \%$ concluded that actually going to these instances, contributed greatly to the cases being resolved quickly and above all fair, since at all times it is the parties who reach an agreement on their conflict. Only $11 \%$ of those surveyed doubted the versatility of the alternative solutions.

Which means that ADRs are effective and efficient, due to the speed in which problems are resolved between the parties involved.

\section{Question 6}

Do you think there is equity of parts in ADRs?

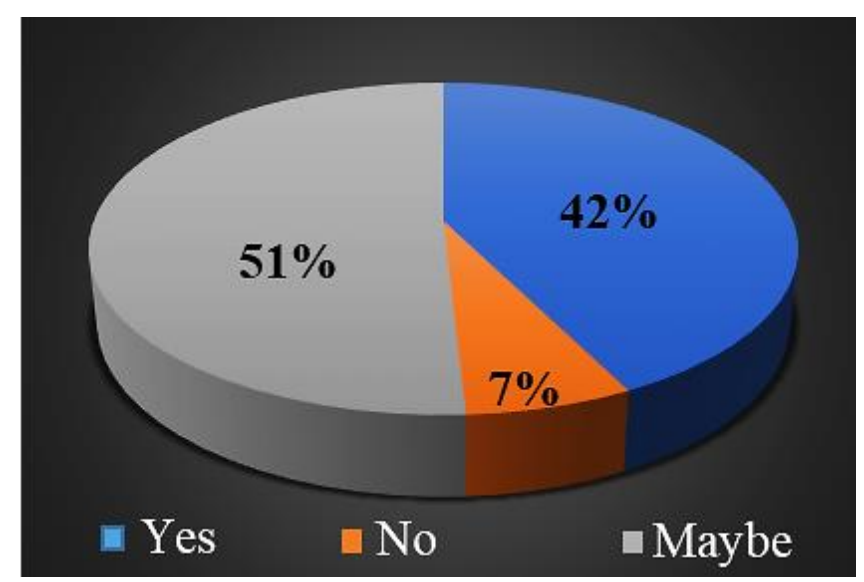

Graphic 7

The purpose of the question in question is to capture how reliable these media could reach when they are made known to the population in an open way, so that people weigh between a lengthy trial and a settlement between parties through the resolution of conflicts that will develop from fast and reliable way. It is necessary that the advantages be made known, only in this way will the company place its trust to resolve legal conflicts in a short time.

$51 \%$ consider that ADRs are an equitable means, however, $42 \%$ do not believe, nor are they convinced that these processes are really fair for the parties; therefore it is necessary for society to identify with them, to know their benefits.

\section{Question 7}

Do you consider it feasible to go to ADRs? 


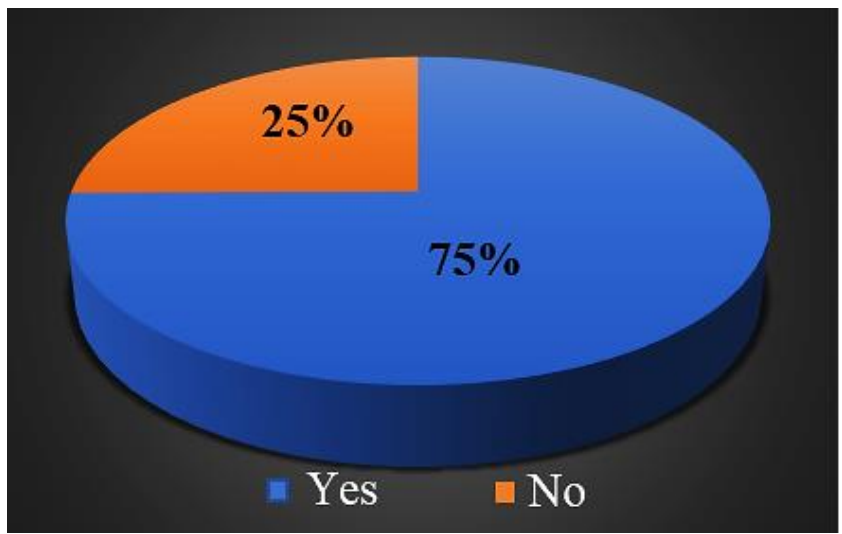

Graphic 8

Respondents found the possibility of going to these media if necessary, as demonstrated by $75 \%$ of the people who indicated that if they consider it feasible to go to an ADR and that therefore they would do it; although 25\% also consider these alternatives to be an unreliable process and therefore they would not go to them and therefore would initiate a traditional judicial process.

The aforementioned shows that the people in conflict do not know the alternative routes such as the dispute resolution mechanisms, if so, they would certainly go to them.

It is necessary to have good communication, information, dissemination and publicity of these mechanisms with everything they offer to help society; this way it could drastically decrease that percentage of people who do not trust them by up to $15 \%$.

\section{Question 8}

Have you advised anyone to go through ADR?

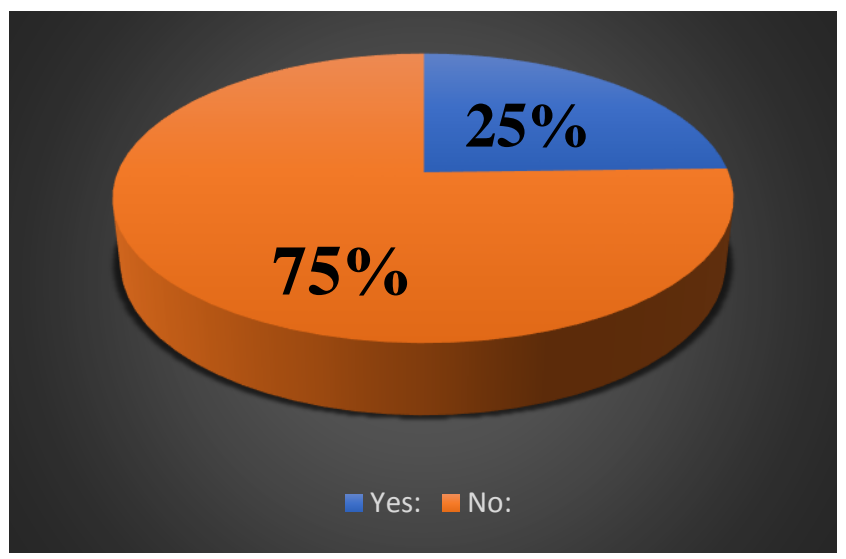

Graphic 9
It is estimated that the respondents representing $75 \%$ do not recommend undergoing $\mathrm{ADR}$, but it is not that they do not want to recommend it, it is simply that they do not know what these mechanisms refer to and, on the other hand, they have not met someone who has used said mechanisms in a legal problem to advise you to go to that alternative medium, to solve your problems.

\section{Question 9}

Do you know any mediation center in your area?

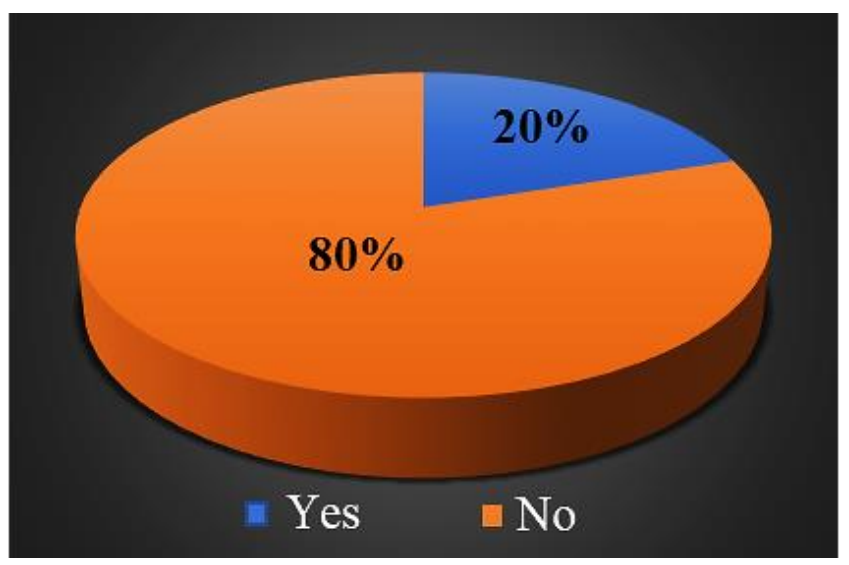

Graphic 10

On the other hand, it can be deduced that many respondents did know what ADR is and others learned it at the time; only 20\% had knowledge of where any of the establishments that carry out these mechanisms were located.

Finally, and in relation to the results of the applied surveys, it can be concluded that society (based on the sample) does not have sufficient knowledge about Alternative Dispute Resolution Means, the few respondents who had already heard about these Alternatives did not have all the data, characteristics, benefits and advantages offered by them; which fully confirms the hypothesis raised at the beginning; "Our society is still unaware of ADRs."

Undoubtedly, the government should put to work in the implementation of the dissemination of these mechanisms, if what they want is to drastically reduce their procedural burden so as not to continue pressuring their judges, they must start promoting and developing strategies to convert alternative means as a mandatory first option for any process, including family. 
As the first option that is proposed, they should begin to fully train all students and legal scholars about these alternative solutions to be able to include them as a recommendation to their clients and acquaintances; in addition to teaching and fulfilling the profile of mediators, conciliators, negotiators and arbitrators.

Finally, begin to inform society about ADRs, advertise in all possible media (television, radio, internet, newspapers, magazines, etc.) the advantages and benefits they present, as well as the simplicity to reach agreements and the zero cost that they would have in case of opting for these mechanisms in public institutions dedicated to it, and a lower cost in private mediation centers, which would avoid them being in the middle of long, expensive and heavy trials.

\section{How could ADRs continue to develop in Mexico?}

Since entering our country, Alternative Dispute Resolution Means have been of great importance in resolving and discharging cases in a short time, considering the time that in a contentious manner would have meant long months to obtain a resolution. However, the Mexican country still has a long way to go to perfect these means and turn them into a more viable, efficient and reliable option; as are the following questions:

Create more spaces and establishments dedicated to ADR, where sessions can also be carried out in a comfortable and harmonious way, properly speaking at the federal, state and municipal levels, both public and private.

- $\quad$ Properly prepare and certify the people who will act in the role of mediator, conciliator or negotiator; The individual cannot be a simple listener, he must have ease of expression, natural communication skills, ability to reduce emotional tension, patience, attitude, listening, who has the necessary knowledge to sculpt ideas by sticking to the case at hand manifesting in an impartial and objective manner as well as the ability to develop techniques and strategies that achieve a change in attitudes between the parties so that they can reach an agreement.
- Finally, continue to develop the appropriate means to be able to fully inform and educate society about the existence of more efficient and faster alternative solutions to resolve their legal problems; begin to eliminate that mentality that the only way to win and obtain the desired claims is by filing a lawsuit, answering it and a long trial where in the end one will win and the other will lose. We must make the population gain confidence about ADRs so that they begin to be seen as something necessary and not as "alternatives".

\section{Final Considerations}

What has been studied up to this point indicates that the Alternative Dispute Resolution Means arrived to establish themselves and continue to evolve until they become the most used legal tool to resolve conflicts in family matters in the country, that they may have the option of doing so.

Despite the ignorance that the population still has regarding these alternatives, it is only a matter of time before they achieve consolidation; This is due to all the excellent results that are being given. More and more agreements are signed and families are leaving the various mediation establishments with justice and satisfaction.

The total acceptance of ADRs will not be achieved nor will they be implemented as a priority to resolve legal issues overnight, everything takes their study, development and optimization to make them more and more efficient; Therefore, more economic and educational resources should be allocated in this area to prepare institutions and professionals in order to continue developing these mechanisms and thus fully involve society with a culture of peace, human rights and everything that it implies.

\section{References}

Contreras, R. (2018). La mediación en México. Excélsior, p.5.

Contreras, R., Roque, E., \& Magallanes, H. (2018). La Justicia Alternativa Áreas de Aplicación de los ADR. México: TRAUCO.

Cornelio, E.

https://www.redalyc.org/articulo.oa?Id=3221/3221 32552006. Octubre 06, 2019, de Redalyc Sitio web: https://www.redalyc.org/articulo.oa?Id=3221/3221 32552006

GONZÁLEZ-HERNÁNDEZ, Daniel Antonio, REJÓN-JIMÉNEZ, Ysela, TEJERO-BOLÓN, Francisco Javier and VÁZQUEZHEREDIA, Pablo Rafael. Alternative dispute resolution (ADR), the best option in family matters. ECORFAN Journal-Mexico. 2020 
Dif.gob.mx. (2016). Modelo Red DIF Para La Solución Pacífica De Conflictos En La Familia. Octubre 04, 2019, de DIF Sitio web: http://dnias.dif.gob.mx/wpcontent/uploads/2018/11/Modelo-RED-DIFActualizado-2016.pdf

Fernández, M. (2017). Los mecanismos de solución de conflictos: una visión alternativa en la impartición de justicia. En DIVULGARE (pp. 430).

Fierro, A. (2017). Los medios alternativos de soluciones de controversias y la reciente reforma a Ley de PAOT. Octubre 05, 2019, de Derecho en Acción Sitio web: http://derechoenaccion.cide.edu/los-mediosalternativos-de-soluciones-de-controversias-y-lareciente-reforma-a-ley-de-paot/

García, M. (2016). Métodos Alternativos de Solución de Controversias. Octubre 06,2019, de MisAbogados.com.mx Sitio web: https://misabogados.com.mx/blog/metodosalternativos-de-solucion-de-controversias/

Gómez, C. (2017). LA MEDIACIÓN EN MATERIA FAMILIAR. Octubre 04, 2019, de Archivos Jurídicas UNAM Sitio web: https://archivos.juridicas.unam.mx/www/bjv/libr os/7/3069/17.pdf

Gómez, E. (2017). "Sistematización de la mediación como medio alternativo para la solución de conflictos familiares: el caso del Centro de Mediación Familiar y Asistencia Jurídica del sistema DIF municipal de Coatzacoalcos, Veracruz (CMFAJ)". Maestría. Universidad Veracruzana.

Gorjón, F. (2014). Métodos Alternativos De Solución De Conflictos. México: OXFORD.

Lara, M. (2018). Medios Alternativos de Solución de Conflictos. Octubre 03, 2019, de Conogasi Sitio web: http://conogasi.org/articulos/mediosalternativos-de-solucion-de-conflictos/

Ley de Mediación y Conciliación del Estado de Campeche.

Luna, M. (2019). Medios alternativos de solución de controversias. Octubre 04, 2019, de El Universal Sitio web: https://www.eluniversal.com.mx/articulo/margar ita-lunaramos/nacion/medios-alternativos-desolucion-de-controversias

ISSN-Print: 2007-1582- ISSN-On line: 2007-3682 ECORFAN $^{\circledR}$ All rights reserved.
Natarén F., González P. \& Witker J. (2016). Las Víctimas En El Sistema Penal Acusatorio. México: Instituto de Investigaciones Jurídicas.

Ocejo, R. (2019). "La Mediación Como Proceso De Gestión De Conflictos. Inducción al derecho de familia.". Licenciatura. Universidad autónoma de San Luis Potosí.

Pérez, J. (2014). "Métodos Alternos de Solución de Conflictos: Justicia Alternativa y Restaurativa para una Cultura de Paz". Maestría. Universidad Autónoma de Nuevo León.

Perea, M. (2018). Matrimonio, Divorcio y Medios Alternativos de Solución de Conflictos. Octubre 04, 2019, de Archivos Jurídicas UNAM Sitio web: https://archivos.juridicas.unam.mx/www/bjv/libros /5/2287/13.pdf

Poder Judicial del Estado de Campeche. (2008). Justicia Alternativa. Octubre 04, 2019, de Centro de Justicia Alternativa Sitio web: https://poderjudicialcampeche.gob.mx/micro\%20j usticia\%20alternativa/index.html

Poder Judicial Del Estado de Sinaloa (2017). Manual general de procedimientos de los centros de mecanismos alternativos de solución de controversias en materia familiar del poder judicial del estado de Sinaloa. Sinaloa.

Red Nacional de Mecanismos Alternativos de Solución de Controversias. (2017). Comisión Nacional del Tribunales Superiores de Justicia de los Estados Unidos Mexicanos (CONATRIB). Octubre 06, 2019, de Red Nacional de Mecanismos Alternativos de Solución de Controversias Sitio web: https://www.pjenl.gob.mx/rednacionalmasc/

Reglamento Del Centro De Justicia Alternativa Del Poder Judicial Del Estado De Campeche.

Reglamento interno del instituto de justicia alternativa del estado. (2014). Jalisco: Instituto de Justicia Alternativa del Estado de Jalisco, p.15.

Rosales, B. (2018). Métodos Alternativos De Solución De Conflictos. DÍKÉ (pp. 23, 257).

Sánchez, M. (2014). Mediación Familiar: Un Proceso Efectivo Para La Solución De Conflictos. En Reseña Jurídica Mediación Familiar (pp. 169175). México: Aequitas. 